\title{
心拍数が音楽聴取時の時間感覚に与える影響
}

\author{
松田 憲*, 一川 誠**, 橘 佳奈* \\ * 山口大学, $* *$ 千葉大学
}

\section{The Influence of Heart Rate on Time Perception during Music Listening}

\author{
Ken MATSUDA*, Makoto ICHIKAWA** and Kana TACHIBANA* \\ * Yamaguchi University, 2-16-1, Tokiwadai, Ube, Yamaguchi 755-8611, Japan \\ ** Chiba University, 1-33, Yayoicho, Inage, Chiba 263-8522, Japan
}

\begin{abstract}
We examined how changes in participants' heart rate affect their estimation of time when listening to music. We manipulated participants' heart rate using a cycling task on an exercise bike and by varying the tempo of music. The heart rates of 48 participants were measured before and after the pedaling task on the exercise bike. One week later, they listened to the music and estimated the temporal duration (60 seconds) under the non-manipulated condition (without exercise) and heart rate manipulated condition (with exercise). The results showed that the duration of the music (60 seconds) was underestimated after light exercise and overestimated after strenuous exercise. These results suggest that the acceleration of the internal time mechanism due to an increase in the heart rate affects the perceived duration of time with relation to music.
\end{abstract}

Keywords : $B G M$, time estimation, heart rate

\section{1. は じめに}

我々は日常生活において, 実際の物理的な時間 (客観的時 間)と自身が感じている時間（主観的時間）が異なるというこ とを度々体験する。このようなズレは，心理学では時間評価 [ある特定の時間の長さをどの程度として見積もる（評価す る)かの問題として調べられている。この時間評価に影響 を及ぼす要因の一つに環境中の刺激のテンポがある。刺激の テンポが速ければその間の時間はより長く感じられやすい.

\subsection{BGMが時間評価に及ぼす影響}

音楽の基本要素であるテンポの好みには精神テンポ（個人 が無意識に選択する好みのテンポ）［1］の関与が想定されて いる [2]. 精神テンポは, 心拍数などの個人の生理周期に依 存しており $[3,4]$, 外的な要因による変動は生じにくい $[5]$. 心拍数と好みのテンポとの関係については, 純音のテンポを 10bpm (beat per minute) から 300bpm まで自由に調節して好 きなテンポを探すという課題において, テンポ比（好みのテ ンポを参加者の心拍数で割ったもの) が 1.0 と $1.5,2.0$ のつ にピークが集まることが示された [6]. さらにメロデイ刺激 としてディズニーのIt's a small worldを用いて同様の手続き

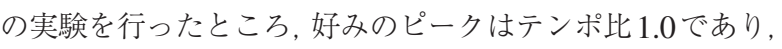
1.5 と 2.0 も同様に高い選択率を示した [7]. よって, テンポの 好みには心拍数とその倍数が関連していることがうかがえる.

また, BGM (Background Music) には, 我々の行動や個々 人が感じる時間経過を変える効果がある. スーパーの BGM のテンポを操作した実験では, 遅いテンポ (72bpm以下) で は速いテンポ (94bpm 以上) と比較して歩行速度が $17 \%$ 遅く
なり，購買金額は38\%上昇した $[8]$ 。レストランで行った 実験で，1分間に食事を口に運ぶ回数を計測したところ， テンポの速いBGM (92bpm以上) では4.4回, 遅い BGM (72bpm 以下) では3.8回であった [9]. 待ち時間中のBGMが 時間評価に及ぼす影響を見た研究では，待ち時間が長い時に はBGMのテンポが速いほうが, 短い時にはテンポが遅いほう が, 経過時間を短く感じることがそれぞれ示された $[10,11]$.

松田・一川・矢倉 [12] は, BGMのテンポと曲中の音符 構成の違いが, BGM聴取時の時間感覚にどのような影響を 与えるのかについて検討した，20名の実験参加者には，作成 した音楽刺激 (2 分音符, 4 分音符, 8 分音符, 2 分音符 4 分 音符混合, 2 分音符 8 分音符混合, 4 分音符 8 分音符混合, 2 分音符 4 分音符 8 分音符混合の 7 種類の音楽条件と, $40 \mathrm{bpm}, 80 \mathrm{bpm}, 120 \mathrm{bpm}, 160 \mathrm{bpm}$ の種類のテンポ条件 を組み合わせたBGM28曲）について1分の経過時間を評価 させた，その結果，テンポ条件と音符条件では，テンポ条件 の方が時間感覚に影響を与えていることが明らかとなった。 テンポは音楽に対する印象を決定するうえで重要な要素であ る $[13,14]$ とともに, 音楽を聴いている時の経過時間の知覚 に影響を与える要素であるということがわかった，最も遅い 40bpmは他のテンポ条件に比べて時間が過小評価（評価した 時間経過が客観的な時間経過に比べて長いことから，評価者 は経過時間を短く感じていると考えられる) され，テンポが 速くなるほど過大評価（評価した時間経過が客観的な時間経 過に比べて短いことから，経過時間を長く感じている)され る傾向にあることが明らかとなった。 さらに，参加者を音楽 経験の有無で分けて同様の検討を行ったところ, 音楽経験の ない参加者は経過時間を過小評価しやすく, 特に遅いテンポ であるほどその傾向が顕著であった. 
しかし, 我々が音楽を耳にする時は必ずしも同じ心身状 態ではない，松田・堀江・一川 [15]は実験前に生理指標を 測定し, その後, エアロバイク運動で参加者の心拍数·体温· 血圧を, 恐怖喚起による心拍数操作 (参加者が音楽聴取して いる間，もしくはストップウォッチを停止した後に風船を 割ると教示) では心拍数・血圧・心理状態をそれぞれ変化さ せた，その後, テンポを実験前に測定した参加者の心拍数 に合わせたBGMを聴かせて産出時間を比較し, これら生理 指標の変化が時間感覚に与える影響を検討した。 その結果, 恐怖喚起による心拍数操作後は, 操作なし状態と比べて時 間が過小評価された。しかし参加者 28 人中 20 人が風船によ る操作時に音楽に集中できなかったと回答していたことか ら, 音楽聴取よりも風船の操作に意識が集中したために, 時間を過小評価したものと考えられる。一方，エアロバイ ク運動後とその他の操作間では産出時間に有意な差は見ら れなかった。これは, 参加者にはエアロバイクを 1 分間全 力で漕ぐように求めたが, その運動量の個人差が大きく, 心的代謝の状態を統制できなかったことが原因ではないか と考えられた。

\section{2 本研究の目的}

本研究では, 松田ほか [15] の研究に基づき, エアロバイ ク運動によって心拍数，血圧，体温を変化させた。 また，同 質の原理（聞き手の気分やテンポと同質の音楽を与えること で，精神的回復に努める）［16］は音楽のリズムにおいても その効果が見られる [17]ことから, エアロバイク運動後に 聴取させる楽曲のテンポを操作なし状態 (安静時)の心拍 数, エアロバイク運動後の心拍数の 2 種類とした。 これらの 心拍数操作条件, 楽曲テンポ条件が産出時間, 感情評価にど のように影響するのかを検討した，また，実験結果に基づき，

BGMなどの音楽を使った心的時間の長さの操作や時間管理 の手法の開発についても検討した

\section{2. 実 験 方 法}

\section{1 要因計画}

エアロバイク運動による心拍数操作 2 水準 $(20 \mathrm{~km} / \mathrm{h}$, $30 \mathrm{~km} / \mathrm{h}$ ) と, 心拍数による楽曲テンポ操作 2 水準（操作なし 状態心拍テンポ, エアロバイク運動後心拍テンポ), 性別 2 水準 (男性, 女性)の3要因参加者間計画であった.

\section{2 実験参加者}

正常な聴力を持つ大学生および大学院生 48 名 (条件ごとに 男女各6名）が実験に参加した. 参加者の平均年齢は21.6歳 であった，実験は個人ごとに行った，エアロバイクの速度設 定によって, 実験参加者の基礎体力や体調次第では実験後に 気分の悪化や身体の不調をもたらす場合があるため, 実験前 にその旨を説明した上で実験参加同意書を提示し, 署名した 者のみを実験参加者として扱った。

\section{3 実験材料}

提示するBGMとして, 松田ほか [15]で用いられたニュー トラル曲 3 曲から 2 曲を選曲した。曲はフリー音楽ソフト (MusicStudioProducer) で作成されたピアノ音の曲（各21 小節）であった，曲はメロディと伴奏で構成され，4/4拍子，

$\mathrm{C}$ 長調とし， $\mathrm{A} 2 \sim \mathrm{E} 4$ の間の白鍵盤のみ (12音) が使用され た.メロディは4分音符, 8 分音符, 16 分音符を使用し, 1 曲に占める音符の割合が 8 分音符が $40 \%, 16$ 分音符が 30\%，4分音符が30\%となるように作成された。

\section{4 測定指標}

身体的代謝に関する生理指標として, 血圧と心拍数, 体温を 測定した．血圧と心拍数は, オムロン自動血圧計 (HEM-7420) を用いて，1週目に操作なし状態，エアロバイク運動による 心拍操作後に測定した. 体温はオムロン電子体温計 $(\mathrm{MC}-612)$ を用いて，1週目の操作なし状態，エアロバイク運動による 心拍数操作直後に腋下の体表にて測定した.

また, 心理指標として, 音楽聴取による感情体験について, 堀田・澤村・井上 [18］を基に，「音楽聴取時の心身の自覚」 について6項目,「音楽聴取時の気分」について6項目, 「(聴いていた) 音楽の印象」について2項目 (各7段階), 「音楽感情価」について12項目 (5段階)，合計26項目を用い て評価を求めた。

\section{5 実験装置}

実験環境は，暗幕で覆われた個室であった。コンピュータ （FUJITSU FMV-S8370）にヘッドホンアンプ（DR.DAC2 DX） を接続し，更にヘッドホン（audio-technica ATH-AD1000） を接続したものを用い，音楽を流した。鹿野［19］より主観 的時間（感じられる時間）は音量によって変動すると考えら れるため, 音量は中程度に固定して行った。時間はストップ ウォッチ（CASIO HS-70W）を用いて計測した。音楽以外の 視聴覚情報に影響されないよう，実験参加者には音楽を聴い ている間アイマスクを着用させた，エアロバイクはST-1030 (スポーツオーソリティ社製)を使用した。

\section{6 手続き}

実験は, 各実験参加者について, 個別実験の形式で, 2 週 にわたって行われた，手続きの概要を図 1 に示す。1 週目は 参加者を暗幕で覆った個室内の椅子に着席させ, 実験手順 (1)操作なし状態で生理指標を測定, (2)エアロバイク運動後 に生理指標を測定）についての説明を行った．2つの操作条 件の順番は，参加者毎にランダムに設定した。エアロバイク の運動速度は，参加者をランダムに $20 \mathrm{~km} / \mathrm{h}, 30 \mathrm{~km} / \mathrm{h} に$ 振り 分けた。エアロバイクには速度が表示される機能が付いてお り，参加者には速度計を見ながら 3 分間指示された速度を 保ったままエアロバイクを漕ぎ続けるよう求めた。

2 週目は, 実験手順の説明を行い, 操作なし・エアロバイ ク運動（1週目と同じ速度）を行った直後，音楽を聴きなが ら 1 分間の時間感覚をストップウォッチで計ってもらった. 

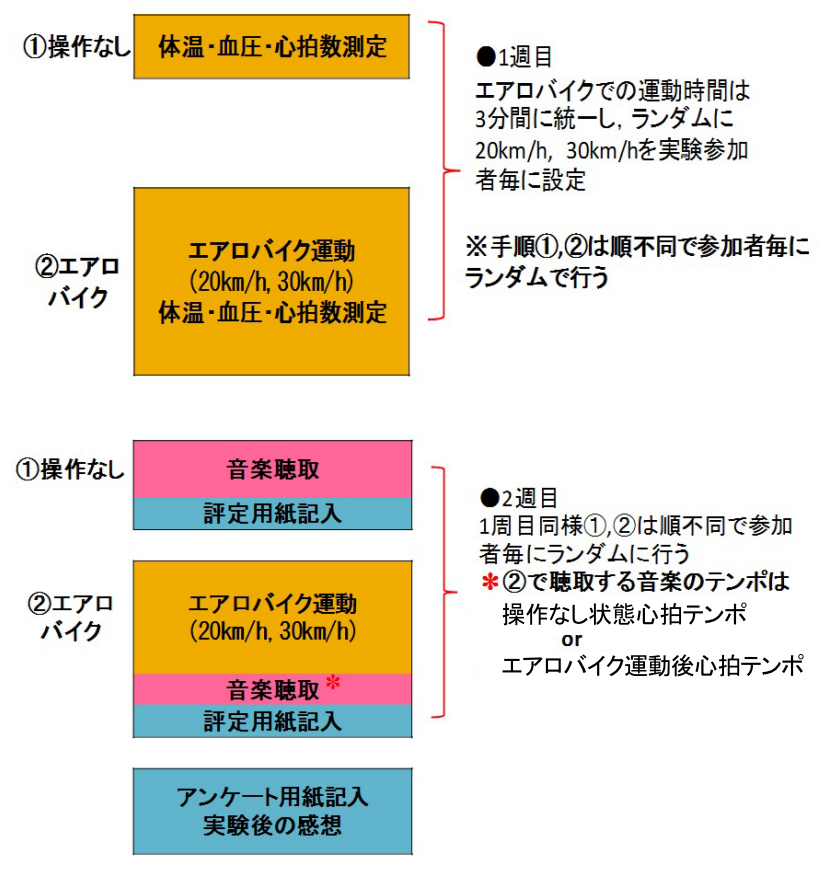

図1実験手続き

1 曲聴取毎に聴取した音楽についての心理評定用紙の記入を 求めた。記入終了後に参加者が安静状態になったのを確認 し, 次の手順へ移った。 これらの参加者の各条件への振り分 けは，全体としてカウンターバランスが取られた。

参加者に操作なし状態で聴取させる曲のテンポは，1週目 に打ける参加者自身の操作なし状態の心拍数とした，また， エアロバイク運動後に聴取させる曲のテンポ条件を操作する ために， $20 \mathrm{~km} / \mathrm{h}, 30 \mathrm{~km} / \mathrm{h}$ それぞれのグループ内で 12 名ず つ2つのグループに振り分けた，一方のグループにテンポを 操作なし状態の心拍数としたものを,もう一方のグループに テンポを 1 週目でのエアロバイク運動後の参加者自身の心拍 数とし, エアロバイク運動後に聴取させた.

時間評価は, 指示された時間 (標準時間) である1分 (60秒) と同じ長さになるように, 実験参加者が主観的に持続時間 (産出時間)を作成する方法 (産出法) で行われた (作成法, 造 成法ともいう). 曲が始まる前に全曲共通の合図音 (woodblock 音)を流し, 曲の開始とともに実験参加者にストップウォッチ を押させた，その後，指示した時間が経過したと思ったとき にストップウォッチを停止させた，カウント，抢よびその他 の評価手がかりを用いないように教示した，最後にアンケー 卜記入と, 口頭で1)普段の生活の中で1分を意識することは あるか，(2)音楽経験の有無，(3)実験全体の意見や感想につい て質問を行い，実験は終了した。

なお, 生理指標の測定と時間評価との間に 1 週間のインター バルを挟んだ理由は以下の 4 点であった. 第 1 に, 本研究では 時間評価の際に流すBGMのテンポを参加者の心拍数で操作 したため, 事前に通常時㧍よび運動後の身体的代謝量を測定 しておく必要があった，第2に，1回目の運動による疲労が 2回目の運動に及ぼす影響を避けるためであった。第3に, 生体リズムが代謝量に及ぼす影響から, 生理指標測定と時間
評価を同一時間带で行うことが求められた，第4に，参加者 である大学生は1週間単位のスケジュールで行動しているこ とが多く，1週後のほうが実駼参加のための時間を確保しや すいためであった１週目と2週目とで, 各参加者の実験は 同等の時間帯で行われたため, 本研究では 1 週目と 2 週目の 参加者の代謝がほぼ同等であると仮定した。

\section{3. 結果と考察}

実験参加者 48 人の操作なし状態の心拍数平均值は $74.98 \mathrm{bpm}(S D=1.67)$ であった. エアロバイク運動 $20 \mathrm{~km} / \mathrm{h}$ の参加者 24 人の心拍数操作後の心拍数上昇值の平均值は $1.58 \mathrm{bpm}$ (男性 $1.17 \mathrm{bpm}$, 女性 $2.00 \mathrm{bpm}$ ) であり, エアロバイク 運動 $30 \mathrm{~km} / \mathrm{h}$ の参加者 24 人の心拍数操作後の心拍数上昇値の 平均值は $17.25 \mathrm{bpm}$ (男性 $12.75 \mathrm{bpm}$, 女性 $21.75 \mathrm{bpm}$ ) であっ た。両条件間の上昇幅の差は有意であり $(F(1,44)=20.09$, $p<.001)$ ，性別抢よび交互作用は有意でなかった．エアロバイ ク運動後の体温変化の性差は有意であり $(F(1,46)=10.67$, $p=.002)$, 男性はエアロバイク運動後に操作なし状態よりも 体温が平均で $0.12^{\circ} \mathrm{C}(S D=0.05)$ 上昇したのに対し，女性は 平均で $0.15^{\circ} \mathrm{C}(S D=0.06)$ 下降した. 産出された時間評価值と 生理指標との相関を見ると, 男性参加者は心拍数操作 $30 \mathrm{~km} / \mathrm{h}$ 条件に扔いて心拍数と産出時間との間に有意な負の相関がみ られ $(r=-.60)$, 心拍数操作 $20 \mathrm{~km} / \mathrm{h}$ 条件では参加者 $(N=12)$ が少ないことから有意ではないものの正の相関が見られた $(r=.45)$. 女性参加者では, 心拍数操作 $30 \mathrm{~km} / \mathrm{h}$ 条件に扔い て心拍数と体温との間の負の相関が有意であった $(r=-.78)$.

エアロバイク運動による心拍数操作 2 水準 $(20 \mathrm{~km} / \mathrm{h}$, $30 \mathrm{~km} / \mathrm{h}$ ) と, 心拍数による楽曲テンポ操作 2 水準（操作なし 状態心拍テンポ, エアロバイク運動後心拍テンポ）の 2 条件 に扔いて, 操作なし状態とエアロバイク運動後の各参加者の 産出時間の平均值と $95 \%$ 信頼区間 (片側) を図 2 に, 男女別 の産出時間を図3に，それぞれ示す。横軸の「操作なし」と 「運動後」は時間評価を行ったのが運動していないかエアロ バイク運動後かを示す. $「 20 \mathrm{~km} / \mathrm{h} 」 と 「 30 \mathrm{~km} / \mathrm{h} 」$ は, エア ロバイク運動による心拍数操作条件 2 水準を,「エアロバイ ク運動後心拍テンポ」と「操作なし状態心拍テンポ」は心拍 数による楽曲テンポ操作条件 2 水準を, それぞれ示すもので ある. 図2が示すように, エアロバイク運動後心拍テンポに 扔ける心拍数操作 $20 \mathrm{~km} / \mathrm{h}$ 条件に打いて, 運動後の産出時間 が標準時間である1分を有意に上回った。

\section{1 性別で実験参加者を分けたとき}

運動による心拍数の変動が実験参加者の産出時間に影響を 及ぼすかを検討するために，参加者ごとのエアロバイク運動 後の産出時間と操作なし状態での産出時間の差分の平均值に ついて $95 \%$ 信頼区間 (片側) を算出し（図4), 基準值0との 比較を行ったところ, 心拍数操作 $20 \mathrm{~km} / \mathrm{h}$ で楽曲テンポ条件 操作なし状態心拍テンポの男性参加者が 0 を有意に上回り, 心拍数操作 $30 \mathrm{~km} / \mathrm{h}$ でテンポ条件エアロバイク運動後心拍 
テンポの男性参加者が有意に下回った。

さらにエアロバイク運動後と操作なし状態における産出 時間の差分について, エアロバイク運動による心拍数操作 条件 $(20 \mathrm{~km} / \mathrm{h}, 30 \mathrm{~km} / \mathrm{h})$ と心拍数による楽曲テンポ操作条件 (操作なし状態心拍テンポ, エアロバイク運動後心拍テンポ), 性別条件 (男性, 女性)の3要因分散分析を行った。その結果, 心拍数操作条件の主効果が有意であった $(F(1,40)=6.11$,

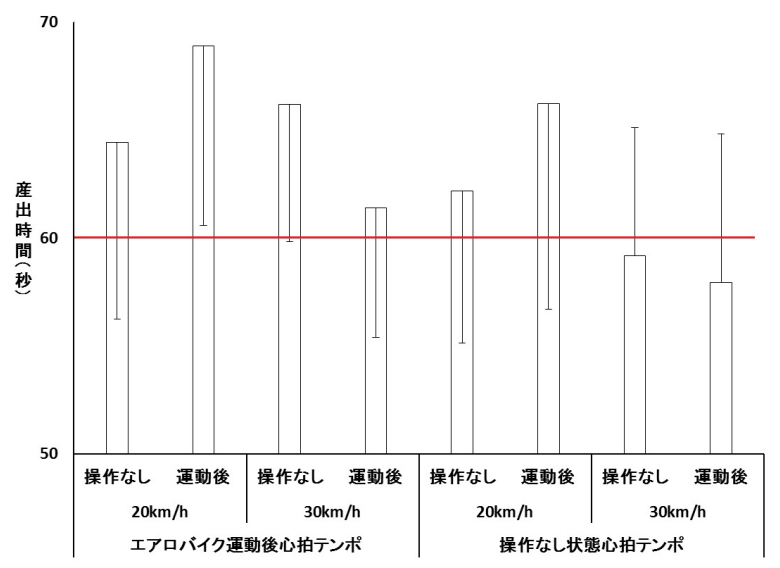

図2 産出時間の平均値。 エラーバーは 95\% 信頼区間（片側）

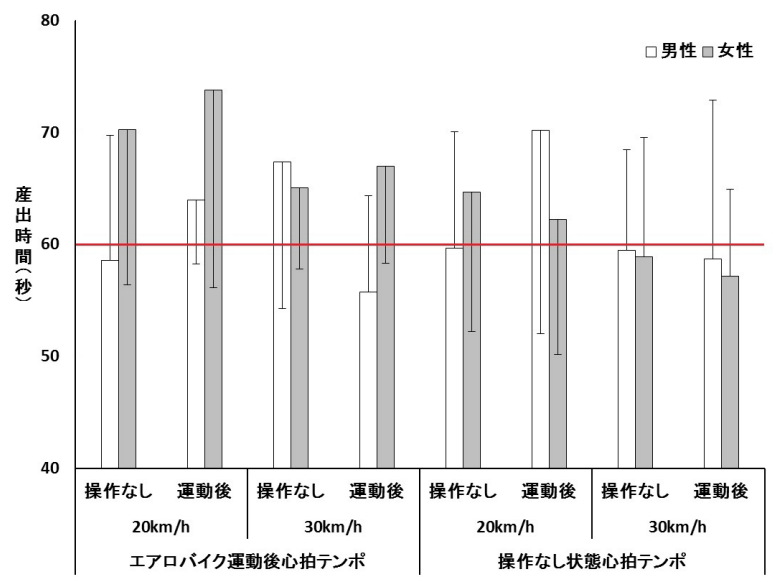

図3 男女別の産出時間の平均値. エラーバーは $95 \%$ 信頼区間（片側）

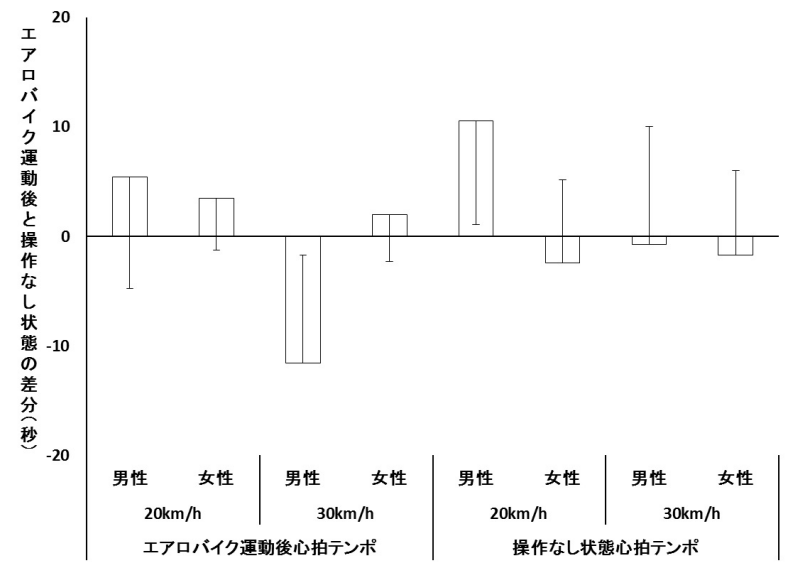

図4 性別で分けた時のエアロバイク運動後と操作なし状態の 差. エラーバーは $95 \%$ 信頼区間（片側） $p=.018)$. また, 性別と心拍数操作条件の交互作用 $(F(1,40)=$ $5.42, p=.025)$ と性別と楽曲テンポ操作条件の交互作用 $(F(1,40)=4.69, p=.037)$ が有意であった．性別と心拍数操 作条件の交互作用に扮ける単純主効果検定の結果，男性の 心拍数操作条件が有意であり $(F(1,40)=11.51, p=.002)$, 心拍数操作 $20 \mathrm{~km} / \mathrm{h}$ 条件における性別の効果が有意傾向であっ た $(F(1,40)=3.18, p=.082)$. 性別と楽曲テンポ操作条件の 交互作用における単純主効果検定の結果, 男性の楽曲テンポ 操作条件が有意傾向であった $(F(1,40)=3.66, p=.063)$.

運動を行っていない安静状態（操作なし条件）と比較し て，エアロバイク $20 \mathrm{~km} / \mathrm{h}$ 運動をした後はより長い時間を産 出（経過時間を過小評価）し，エアロバイク $30 \mathrm{~km} / \mathrm{h}$ 運動の 後はより短い時間を産出（経過時間を過大評価）しやすいこ とが分かった。ささらに，心拍数が上がっていないときには遅 いテンポの音楽, 心拍数が上昇した時にはテンポの速い音楽 というように，聴取する BGM と身体反応が文脈的に同期し ていることが重要であった。これらの原因として，エアロバ イク $30 \mathrm{~km} / \mathrm{h}$ 運動後は脳内の酸化新陳代謝速度が速くなった (脳内のどこかにあると想定される「内的時計」の進み方が 速くなった）ために，時間を過大評価（経過時間を短く感じ る）した [20]のではないかと考えられる。一方で，エアロ バイク $20 \mathrm{~km} / \mathrm{h}$ 運動では逆に過小評価につながったことにつ いて，たとえばカフェインを摂取した直後や風呂に入った直 後は代謝が上がり，その後急速に代謝が低下し，その夕イミ ングで入眠し易くなる $[21]$. 今回の実験でも, エアロバイク $20 \mathrm{~km} / \mathrm{h}$ 運動の直後にはむしろ代謝が低下したことが時間感 覚の過小評価を生起させた可能性が考えられる。

またエアロバイク $30 \mathrm{~km} / \mathrm{h}$ 運動後には, 男性の方が, 女性と 比較して, 心拍操作条件とテンポ操作条件の影響を受けやす く, 経過時間を過大評価(経過時間を長く感じる) しやすい ことが明らかになった。この要因として，運動により増加し た代謝速度に男女差がある可能性が挙げられる。しかし男女 とも負荷した運動強度は同一であり, したがって運動によっ て増加した消費エネルギーも同一であることから，代謝速度 の増加に男女差はないはずである。ただし，身体全体の代謝 速度と脳内の代謝速度が同一である保証はなく，また脳内の 新陳代謝過程が「内的時計」の進み方に及ぼす影響に男女差 がある可能性は否定できない

一方, 男性では $30 \mathrm{~km} / \mathrm{h}$ の運動後の心拍数増加と産出時間 の間に有意の負の相関が認められまた $20 \mathrm{~km} / \mathrm{h}$ 運動後の 心拍数と産出時間の間にも有意ではないが相関が認められて いるが，女性では相関関係は認められていない。自転車運動 などの有酸素性運動では, 運動により上昇する心拍数の程度 は運動強度（代謝速度：消費カロリー）に依存するが，持久性 体力にも依存する [22]。運動生理学でいう体力とは外界から の刺激に対する生体の耐性の指標であり，言い換えれば刺激 により生体に生じる反応の総合的な大きさ（負担度）の指標で あると考えられる。一定強度の有酸素運動をした際の心拍数 とその人に可能な最大運動時の心拍数 (毎分「220-年齢」と して予測される) との比 (\%最大心拍数：相対的運動強度) 
は持久性体力の指標として運動処方をする際などに用いられ ていて [22], 持久性体力が低いほど大きく高いほど小さい. 本研究で得られた\%最大心拍数はエアロバイク $20 \mathrm{~km} / \mathrm{h}$ 運動 では平均 $38.77 \%$ （男性 $39.16 \%$ ，女性 38.38\%）であり，エア ロバイク $30 \mathrm{~km} / \mathrm{h}$ 運動では平均 $46.31 \%$ (男性 $44.31 \%$, 女性 $48.32 \%$ ) であった。図 $5 に, 30 \mathrm{~km} / \mathrm{h}$ 運動時の \% 最大心拍数 を横軸に，産出時間を縦軸にとった散布図を示す。男性では $\%$ 最大心拍数が大きく体力が低いと考えられる参加者では 産出時間が短く時間を過大評価する傾向が認められるが, 女性では体力が低くても時間を過大評価する参加者は少な い. 本研究で負荷した $30 \mathrm{~km} / \mathrm{h}$ 運動水準の強度は中程度の強 度に相当し [23], 相対的運動強度は男女とも30〜60\%程度 の範囲に分布する。このような強度と負担度の運動では代謝 速度の増加よりも生体の負担度による影響の方が大きく, 負担度の影響には男女差があると考えれば本研究の成績は矛 盾なく説明できる。

また, 先行研究によって体温が高い状況下で時間感覚が加 速すること $[24,25]$ ，暑熱環境下では男性のほうが女性よ りも運動終了後の貯熱量が高いこと [26] が示されている. 本研究の相関分析の結果からも, 女性は心拍数と体温に負の 相関が得られている. しかし, 本研究での体温測定は体表温 度のみであり，運動による体温の変動も微小であった。

今後は, 脳内の代謝速度を実際に測定する, より強度 （消費カロリー）の高い運動を負荷する，あるいは深部体温の 測定なども加えたより詳細な研究が必要であろう。さらに, 本研究では参加者には運動しやすい服装で実験に参加するこ とを求めたが, 着衣量を完全にコントロールしていなかった。 室温や湿度といった実験室内環境の統制もとくには行ってい ない. 今後の実験では, 温熱 6 要素をパラメータとして産出 される予測平均温冷感 (Predicted Mean Vote：PMV) [27] を操作して, 温熱環境が時間評価にどのような影響を及ぼす かについても検討を行っていきたい.

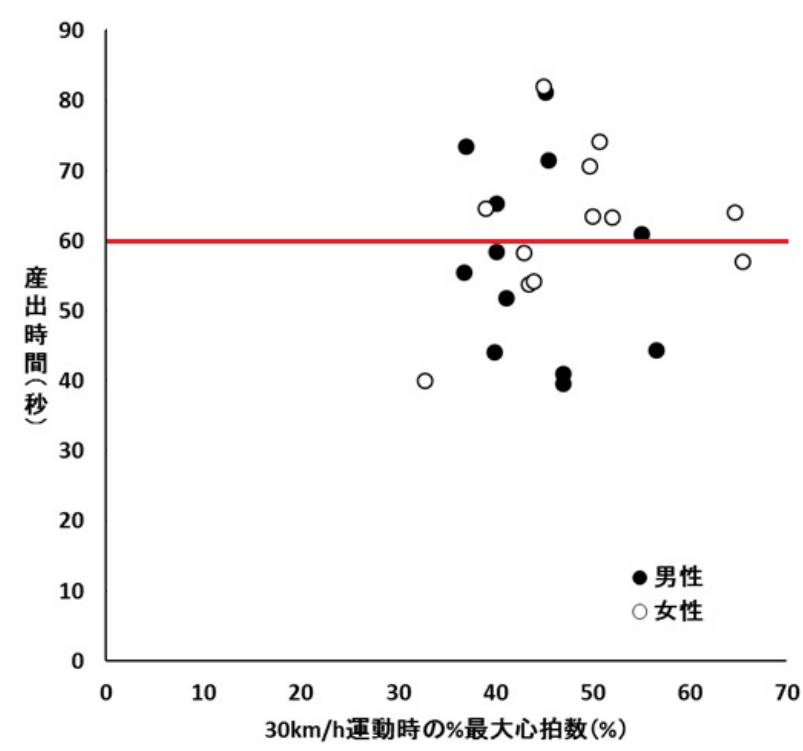

図5 エアロバイク $30 \mathrm{~km} / \mathrm{h}$ 条件における産出時間と $\%$ 最大心拍数の散布図

\section{2 音楽経験の有無で実験参加者を分けたとき}

実験後に記入を求めた音楽経験の有無についてのアンケー 卜結果より参加者 48 名を 2 群に分けた（図6). エアロバイ ク運動後心拍テンポ条件において, 音楽経験のある参加者は 13 名 $(20 \mathrm{~km} / \mathrm{h}$ 条件：男性 2 名, 女性 5 名, $30 \mathrm{~km} / \mathrm{h}$ 条件：男性 2 名, 女性 4 名), 音楽経験のない参加者は 11 名 $(20 \mathrm{~km} / \mathrm{h}$ 条件： 男性 5 名, 女性 1 名, $30 \mathrm{~km} / \mathrm{h}$ 条件: 男性 4 名, 女性 2 名) であっ た，操作なし状態心拍条件では，音楽経験のある参加者は 14 名 $(20 \mathrm{~km} / \mathrm{h}$ 条件：男性 2 名, 女性 5 名, $30 \mathrm{~km} / \mathrm{h}$ 条件：男性 2 名, 女性 5 名), 音楽経験のない参加者は 10 名 $(20 \mathrm{~km} / \mathrm{h}$ 条件： 男性 4 名, 女性 1 名, $30 \mathrm{~km} / \mathrm{h}$ 条件: 男性 4 名, 女性 1 名)であった。 基準值 0 との比較において, 音楽経験のある参加者は, 心拍数操作 $20 \mathrm{~km} / \mathrm{h}$ でテンポ条件エアロバイク運動後心拍 テンポ条件の時に，時間を過小評価した。また，心拍数操作 条件と楽曲テンポ操作条件に音楽経験条件 (参加者間 : 経験 あり, 経験なし) を加え, 3要因2水準の分散分析を行った結果, 心拍数操作条件の主効果, 楽曲テンポ操作条件と音楽経験の 交互作用がそれぞれ有意であった $(F(1,40)=5.22, p=.028$ ； $F(1,40)=4.45, p=.041)$. 単純主効果検定の結果, 音楽経 験なし条件における楽曲テンポ操作条件が有意傾向であり $(F(1,40)=4.01, p=.051)$, エアロバイク運動後心拍条件に おける音楽経験が有意であった $(F(1,40)=4.16, p=.048)$. これらの結果から, 音楽経験のある人は運動後に時間を過小 評価(経過時間を長く感じる) しやすく，音楽経験のない人は 楽曲テンポや心拍数変化に影響を受けやすいことが導ける.

イベントの数が多いと時間が過大評価される現象を充実時 程錯覚と言う。松田ほか [12]の先行研究では, テンポが遅 い時には充実時程錯覚とは逆に時間の過小評価が生じること が示されている。音楽経験者は楽曲の音や演奏, フレーズな どに注意が向くことで多くのイベントを体験するのに対し, 非経験者はメロデイをひとまとまりのものとして聴いている 可能性が考えられる. 本研究の心拍数操作 $20 \mathrm{~km} / \mathrm{h}$ 条件での 過小評価は, 音楽経験者が体験したイベントの数による逆充 実時程錯覚によると考えられる. 松田ほか [12]の実験では, 音楽経験者よりもむしろ非経験者のほうが産出時間は過小評 価される傾向にあり, 本研究とは逆の結果となった. 先行研

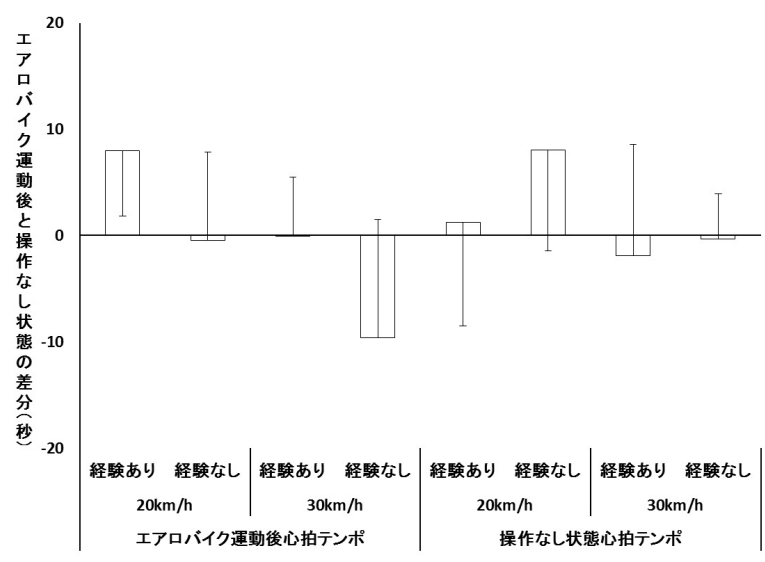

図6 音楽経験で分けた時のエアロバイク運動後と操作なし 状態の差. エラーバーは 95\% 信頼区間（片側） 
究では心拍数の操作は行っていないために単純に比較するこ とはできないが, この結果の差異は用いた楽曲の違いが影響 していることが考えられる. 先行研究 [12]で用いた楽曲は 1小節ごとに音符数が操作されていたことからメロディの凝 集性が低く，まとまって認識されにくかったことが考えられ る。 そして, 音楽刺激への新奇性認知が時間を過小評価させ たのではないだろうか. 本研究と同様の音楽刺激を用いた先 行研究 [15]では, 音楽経験の有無による時間評価の有意な 差は見られなかったが, そこでは参加者にエアロバイクを全 力で漕がせた後に聴取させた音楽のテンポは $80 \mathrm{bpm} に$ 固定 されていた，そのため, 条件としては本研究における操作な し状態心拍テンポ条件の $30 \mathrm{~km} / \mathrm{h}$ 条件に相当するものと考え られ, 本研究と同様の結果が得られていると言える.

また, 本研究の参加者は, 音楽経験あり群は女性が, 経験 なし群は男性が多かった。この比率の違いが結果に影響した 可能性がある. 特に, エアロバイク運動後心拍テンポ条件に おける心拍数操作 $30 \mathrm{~km} / \mathrm{h}$ と, 操作なし心拍テンポ条件にお ける心拍数操作 $20 \mathrm{~km} / \mathrm{h}$ において, 男性参加者と経験なし群
の時間評定值が非常に類似している, そのため, 性差と音楽 経験の要因が交絡している可能性が考えられる。両者を分離 あるいは因果関係を示すためにも, 音楽経験の有無の男女比 を揃えて実験を行う必要があるだろう。

\section{3 心理指標の評定値の分析}

心理指標の評定結果を表 1 と表 2 に示す. 各心拍数操作条 件において，心理評定值の間に有意な差があったかどうかを 確認するために, 参加者内 1 要因（評定時期条件：操作なし 状態, エアロバイク運動後), 参加者間 2 要因 (心拍数操作 条件, 楽曲テンポ条件) の3 要因分散分析を行った。

音楽を聴いていた時の気分について，「気持ちが悪くなるー 気持ちが良くなる」の項目において, 心拍数操作条件と楽曲 テンポ条件の交互作用が有意であった $(F(1,44)=6.90$, $p=.012$ ). 楽曲テンポは音楽を聴いていた時の気持ちを左右 し, 特に $30 \mathrm{~km} / \mathrm{h}$ 運動後には速いテンポの楽曲の方が気持ちを 良くすることが明らかとなった。また，「騒々しいー穏やか」 の項目において, 評定時期条件で有意傾向が見られた

\section{表1 各心理評定の平均値と標準偏差}

《音楽を聴いていた時の気分について》

\begin{tabular}{|c|c|c|c|c|c|c|c|c|c|c|}
\hline & \multicolumn{2}{|c|}{$\begin{array}{c}\text { 操作なし状態 } \\
\text { 操作なし状態心拍テンポ }\end{array}$} & \multicolumn{2}{|c|}{$\begin{array}{c}\text { エアロバイク20km/h } \\
\text { 操作なしし状態心拍テンポ }\end{array}$} & \multicolumn{2}{|c|}{$\begin{array}{c}\text { エアロバイク20km/h } \\
\text { エアロパイク後心拍テンポ }\end{array}$} & \multicolumn{2}{|c|}{$\begin{array}{c}\text { エアロバイク } 30 \mathrm{~km} / \mathrm{h} \\
\text { 操作なし状態心拍テンポ }\end{array}$} & \multicolumn{2}{|c|}{$\begin{array}{c}\text { エアロバイク } 30 \mathrm{~km} / \mathrm{h} \\
\text { エアロバイク後心拍テンポ }\end{array}$} \\
\hline & $M$ & $S D$ & $M$ & $S D$ & $M$ & $S D$ & $M$ & $S D$ & $M$ & $S D$ \\
\hline 不快一快 & 5.21 & 0.10 & 5.17 & 0.17 & 5.17 & 0.24 & 5.25 & 0.22 & 5.50 & 0.31 \\
\hline 気持ちが悪くなる一気持ちが良くなる & 5.21 & 0.12 & 5.33 & 0.26 & 5.17 & 0.30 & 4.92 & 0.19 & 5.50 & 0.23 \\
\hline 気分が落ち込む一元気が出る & 4.63 & 0.13 & 4.42 & 0.40 & 4.42 & 0.34 & 4.50 & 0.26 & 5.25 & 0.33 \\
\hline 騷々しい—穞やか & 5.71 & 0.14 & 5.33 & 0.33 & 5.25 & 0.35 & 5.67 & 0.31 & 5.17 & 0.42 \\
\hline 疲れる一楽 & 5.44 & 0.15 & 5.17 & 0.27 & 5.17 & 0.27 & 5.33 & 0.28 & 5.42 & 0.38 \\
\hline 消極的な気分一積極的な気分 & 4.19 & 0.16 & 4.25 & 0.35 & 4.42 & 0.29 & 4.25 & 0.33 & 4.75 & 0.45 \\
\hline
\end{tabular}

《音楽を聴いていた時の心身の自覚について》

\begin{tabular}{|c|c|c|c|c|c|c|c|c|c|c|}
\hline & \multicolumn{2}{|c|}{$\begin{array}{c}\text { 操作なし状態 } \\
\text { 操作なし状態心拍テンポ }\end{array}$} & \multicolumn{2}{|c|}{$\begin{array}{c}\text { エアロバイク20km/h } \\
\text { 操作なし状態心拍テンポ }\end{array}$} & \multicolumn{2}{|c|}{$\begin{array}{c}\text { エアロバイク } 20 \mathrm{~km} / \mathrm{h} \\
\text { エアロパイク後心拍テンポ }\end{array}$} & \multicolumn{2}{|c|}{$\begin{array}{c}\text { エアロバイク } 30 \mathrm{~km} / \mathrm{h} \\
\text { 操作なし状態心拍テンポ }\end{array}$} & \multicolumn{2}{|c|}{$\begin{array}{c}\text { エアロバイク } 30 \mathrm{~km} / \mathrm{h} \\
\text { エアロバイク後心拍テンポ }\end{array}$} \\
\hline & $M$ & $S D$ & $M$ & $S D$ & $M$ & $S D$ & $M$ & $S D$ & $M$ & $S D$ \\
\hline 心地悪い—心地良い & 5.35 & 0.11 & 5.25 & 0.22 & 5.33 & 0.22 & 5.08 & 0.29 & 5.58 & 0.31 \\
\hline 目がさえる一眠くなる & 5.25 & 0.16 & 5.08 & 0.29 & 4.33 & 0.41 & 4.83 & 0.49 & 4.08 & 0.43 \\
\hline イライラする一落ち着く & 5.63 & 0.11 & 5.25 & 0.30 & 5.33 & 0.28 & 5.17 & 0.37 & 5.50 & 0.34 \\
\hline 緊張する—リラックスする & 5.56 & 0.13 & 5.17 & 0.32 & 5.17 & 0.39 & 5.50 & 0.34 & 5.33 & 0.31 \\
\hline 疲れる一楽 & 5.35 & 0.12 & 5.25 & 0.28 & 5.17 & 0.32 & 4.83 & 0.27 & 5.50 & 0.34 \\
\hline 不安一安心 & 5.42 & 0.14 & 4.83 & 0.34 & 5.00 & 0.30 & 5.33 & 0.26 & 5.50 & 0.38 \\
\hline
\end{tabular}

\begin{tabular}{|c|c|c|c|c|c|c|c|c|c|c|}
\hline & \multicolumn{2}{|c|}{$\begin{array}{c}\text { 操作なし状態 } \\
\text { 操作なし状態心拍テンポ }\end{array}$} & \multicolumn{2}{|c|}{$\begin{array}{c}\text { エアロバイク20km/h } \\
\text { 操作なし状態心拍テンポ }\end{array}$} & \multicolumn{2}{|c|}{$\begin{array}{c}\text { エアロバイク20km/h } \\
\text { エアロパイク後心拍テンポ }\end{array}$} & \multicolumn{2}{|c|}{$\begin{array}{c}\text { エアロバイク } 30 \mathrm{~km} / \mathrm{h} \\
\text { 操作なし状態心拍テンポ }\end{array}$} & \multicolumn{2}{|c|}{$\begin{array}{c}\text { エアロバイク } 30 \mathrm{~km} / \mathrm{h} \\
\text { エアロバイク後心拍テンポ }\end{array}$} \\
\hline & $M$ & $S D$ & $M$ & $S D$ & $M$ & $S D$ & $M$ & $S D$ & $M$ & $S D$ \\
\hline 嫌い—好き & 5.06 & 0.11 & 5.08 & 0.26 & 4.83 & 0.21 & 4.92 & 0.23 & 5.58 & 0.26 \\
\hline 速い—遅い & 4.54 & 0.17 & 4.00 & 0.28 & 4.42 & 0.26 & 4.33 & 0.40 & 3.58 & 0.26 \\
\hline
\end{tabular}

表2 音楽感情価の平均値と標準偏差

\begin{tabular}{|c|c|c|c|c|c|c|c|c|c|c|}
\hline & \multicolumn{2}{|c|}{$\begin{array}{c}\text { 操作なし状態 } \\
\text { 操作なし状態心拍テンポ }\end{array}$} & \multicolumn{2}{|c|}{$\begin{array}{c}\text { エアロパイク } 20 \mathrm{~km} / \mathrm{h} \\
\text { 操作なし状態心拍テンポ }\end{array}$} & \multicolumn{2}{|c|}{$\begin{array}{c}\text { エアロバイク } 20 \mathrm{~km} / \mathrm{h} \\
\text { エアロバイク後心拍テンポ }\end{array}$} & \multicolumn{2}{|c|}{$\begin{array}{c}\text { エアロバイク } 30 \mathrm{~km} / \mathrm{h} \\
\text { 操作なし状態心拍テンポ }\end{array}$} & \multicolumn{2}{|c|}{$\begin{array}{c}\text { エアロバイク } 30 \mathrm{~km} / \mathrm{h} \\
\text { エアロバイク後心拍テンポ }\end{array}$} \\
\hline & $M$ & $S D$ & $M$ & $S D$ & $M$ & $S D$ & $M$ & $S D$ & $M$ & $S D$ \\
\hline 明るい & 3.83 & 0.13 & 3.92 & 0.34 & 3.25 & 0.25 & 4.25 & 0.18 & 4.50 & 0.15 \\
\hline 悲しい & 2.42 & 0.17 & 1.83 & 0.24 & 2.50 & 0.38 & 2.00 & 0.30 & 1.75 & 0.22 \\
\hline 優しい & 4.02 & 0.12 & 3.75 & 0.30 & 3.83 & 0.17 & 4.42 & 0.19 & 3.50 & 0.34 \\
\hline 刺激的な & 1.60 & 0.14 & 1.75 & 0.28 & 1.67 & 0.28 & 1.58 & 0.34 & 2.25 & 0.37 \\
\hline 浮かれた & 2.63 & 0.16 & 2.58 & 0.29 & 2.42 & 0.34 & 2.42 & 0.31 & 2.92 & 0.36 \\
\hline 厳かな & 2.15 & 0.15 & 2.25 & 0.25 & 1.83 & 0.30 & 1.75 & 0.28 & 1.83 & 0.24 \\
\hline 楽しい & 3.56 & 0.13 & 3.33 & 0.33 & 3.92 & 0.19 & 4.00 & 0.25 & 4.33 & 0.14 \\
\hline 暗い & 2.17 & 0.14 & 2.50 & 0.42 & 1.75 & 0.18 & 1.67 & 0.33 & 1.67 & 0.19 \\
\hline おだやかな & 4.17 & 0.13 & 3.75 & 0.30 & 3.92 & 0.29 & 4.08 & 0.29 & 3.33 & 0.36 \\
\hline 強い & 1.85 & 0.14 & 2.17 & 0.30 & 2.17 & 0.27 & 1.42 & 0.19 & 2.75 & 0.28 \\
\hline 落ち着きのない & 1.98 & 0.15 & 2.25 & 0.41 & 2.00 & 0.25 & 1.92 & 0.29 & 2.25 & 0.30 \\
\hline 気高い & 2.48 & 0.15 & 2.75 & 0.30 & 2.08 & 0.26 & 1.92 & 0.31 & 2.92 & 0.34 \\
\hline
\end{tabular}


$(F(1,44)=3.29, p=.076)$. 評定平均值は操作なし状態の心 拍数 (3 条件) がエアロバイク運動後の心拍数操作 (2 条件) よりも高いことから, 操作なし状態の心拍数のテンポの楽曲 の方が，穏やかな気分になる傾向にあった。

音楽聴取時の心身の自覚について,「イライラする一落ち 着く」の項目において, 評定時期条件が有意傾向であり $(F(1,44)=3.23, p=.079),\lceil$ 目がさえる一眠くなる」にお いて, 評定時期条件が有意であり $(F(1,44)=9.37, p=.004)$, 楽曲テンポ条件と評定時期条件の交互作用が有意傾向であっ た $(F(1,44)=3.66, p=.062)$. 操作なし状態で楽曲を聴いて いるときが最も落ち着いている一方で, 運動後には目がさ え, 特に運動後の心拍数と同じテンポの楽曲を聴くことで目 がさえやすいという結果となった

音楽の印象については,「嫌い一好き」の項目において, 心拍数操作条件と楽曲テンポ条件の交互作用が有意であり $(F(1,44)=6.21, p=.017)$, 評定時期条件と心拍操作条件 の交互作用が有意傾向であった $(F(1,44)=3.40, p=.072)$. エアロバイク運動後の心拍数とすることで, 楽曲への好意度 が大きく左右される傾向にあった。 また, 聴取時の気分の結果 と同様に, $30 \mathrm{~km} / \mathrm{h}$ 運動後には心拍数の上昇に合わせたテンポ の速い楽曲が好まれることが明らかとなった。「速いー遅い」 において, 評定時期条件が有意傾向であり $(F(1,44)=3.67$, $p=.062), 3$ 要因の交互作用が有意傾向であった $(F(1,44)=$ $3.67, p=.062)$. 体感的な楽曲テンポは, 本来の楽曲テンポ だけでなく, 運動の前後, また運動の強度などによって左右 される傾向にあった，特に，エアロバイク $30 \mathrm{~km} / \mathrm{h} て ゙ は$ 他の 条件と比較して楽曲のテンポを遅く感じており, 中程度の 運動の時に内的時間の加速が顕著であったと考えられる.

音楽感情価について, 「明るい」の項目に拈いて心拍数操 作条件が有意であり $(F(1,44)=9.08, p=.004), 30 \mathrm{~km} / \mathrm{h}$ 運 動後には, 聴取する楽曲に明るい印象を持つ結果となった。 「優しい」の項目において, 心拍数操作条件と楽曲テンポ条 件の交互作用が有意傾向であり $(F(1,44)=3.51, p=.068)$ ， 楽曲テンポ条件と評定時期条件の交互作用が有意であった $(F(1,44)=6.20, p=.017)$. 操作なし状態の方が楽曲に優し い印象を抱きやすい傾向にあり, エアロバイク運動後の心拍 数の楽曲の場合には, その傾向が顕著であった。「おだやか な」の項目においても同様の結果であった。 その他の項目は 評定平均值が中央值 3 を回ったことから, 聴取した音楽の 感情価として適合性が低かったと言える.

\section{4. まとめ}

本実験の結果より，エアロバイク $30 \mathrm{~km} / \mathrm{h}$ 運動での心拍数の 上昇による内的時間の加速が時間評価に強い影響を与えてい ると言える。，心理指標との関係については，エアロバイク $30 \mathrm{~km} / \mathrm{h}$ 運動後に速いテンポの楽曲を聞いた時には参加者は気 持ちがいいと感じていた，その楽曲を肯定的に評価していた にもかかわらず, 経過した時間の長さは過大評価されていた。 この結果は,「楽しい時間ほど短く感じる」という一般的な感
覚とは反対の傾向であった。「楽しい時間」は何か楽しい課題 に取り組んでいる時に, その課題に注意が向きがちになり, 時間経過に注意が向かないことが関係しているという解説が 多い [20]. 課題の楽しさではなく気分的な楽しさについての 評価は, 課題や時間経過に対する注意とは直接的に対応する ものではないのだろう. 他方, 心拍数などで見られる生理的状 態は感じられる時間と強い対応づけがあるものと考えられる.

実験結果に基づき，BGMなどの音楽を使った心的時間の 長さの操作や時間管理の手法の開発についても検討した。 男性に関しては，さまざまなテンポの音楽を流すことで主観 的時間を有意に操作できることが分かった。つまり，安静時 と比較して, エアロバイク $30 \mathrm{~km} / \mathrm{h}$ 運動の後はテンポの速い 音楽の聴取により経過時間がより長く感じられ，エアロバイ ク $20 \mathrm{~km} / \mathrm{h}$ 運動の後にはゆっくりした音楽で経過時間が短く 感じられた。この傾向を利用すると, 男性に関しては, 待ち 時間を短くするためには, 相対的運動強度が $30 \%$ 程度の緩 やかな運動の後にゆったりした音楽を聴かせるのが有効であ ろう。たとえば, 階段の昇降や比較的長い距離を歩行のあと に入る部屋は, 待ち時間を長く感じさせない待合室として有 用と考えられる。また，楽しく感じられるような時間を長引 かせるには, 中程度の強度の運動などで代謝を挙げつつ, テ ンポの速いBGMを流すのが有効と言えるだろう。代謝が上 がるようなスポーツを娛楽として楽しむ場合, 速いテンポの BGMをかけておくと，その間の時間をより長く感じること を可能にするものと期待できる. 今後, 女性に関しても, BGMなどの音楽を使った心的時間の長さの有効な操作法や 時間管理法についても特定したい.

\section{5. 今後の課題}

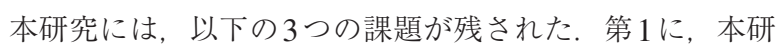
究の心拍数操作条件ではエアロバイクを漕ぐ速度で心拍数を 操作したが, $20 \mathrm{~km} / \mathrm{h}$ 条件では参加者 24 人の心拍数の変域は 24 人中 23 人が $\pm 10 \mathrm{bpm}$ 以内であった。一方で $30 \mathrm{~km} / \mathrm{h}$ 条件 では，ほとんど変化の見られない者から $63 \mathrm{bpm}$ 上昇した者 まで多様であった，第2に, 本研究では, 1 週目に生理指標を, 2 週目に産出時間を測定した. 1 週間後にも生理指標の数值 に一貫性が保たれているという仮定の下に実験を行ったもの の, 1 週間のインターバルによる数值の変動があった可能性 が考えられる。第 $3 に$, 本研究で運動後に測定した生理指標 は運動直後の值であるが，時間評価のための 1 分間に低下し た可能性がある，特に，ゆっくりした運動後の時間の過大評 価が運動後の代謝の低下によるという仮説を検証するために も，運動後の代謝量の変動を記録する必要がある。これら 3つの課題を解決するために, 今後は血流計等を用いて生理 指標を直接リアルタイムで測定して楽曲テンポを操作するこ とを検討したい.リアルタイムでの代謝量測定值をバイオ フィードバックのように参加者に呈示することで, 心拍数操 作条件の妥当性向上が期待される. 本研究で 2 週に分けて行っ た生理指標測定と時間評価を同時に行えるため, 代謝量の 
一貫性が保証される。 さらに時間評価を行っている間も生理 指標の測定が可能であるため, ゆっくりした運動後の時間の 過大評価について, 代謝量と関連付けた考察が可能となる.

\section{参 考 文 献}

[1] Temperley, N. M.: Personal tempo and subjective accentuation, Journal of General Psychology, 78, pp.267-287, 1968.

[2] Buchanan, J. C.: An exploratory study of preschool children's synchronization of a selected rhythmic activity with music set at their heart rates, Unpublished Ph. D. dissertation, University of South Florida, 1988.

[3] Fraisse, P.: Rhythm and tempo, In D. Deutsch (Ed.), Psychology of Music, New York, Academic Press, pp.149-180, 1982.

[4] Marriott, H. L. J.: Practical electrocardiography, Baltimore, MD, Williams \& Wilkins, 1977.

[5] Deutsch, D. : 音楽の心理学 (上) 監訳: 寺西立年·大串健吾· 宮崎謙一, 西村書店, 1987.

[6] Iwanaga, M.: Harmonic relationship between preferred tempi and heart rate, Perceptual and Motor Skills, 81, pp.67-71, 1995.

[7] Iwanaga, M.: Relationship between heart rate and preference for tempo of music, Perceptual and Motor Skills, 81, pp.435-440, 1995.

[8] Milliman, R. E.: Using background music to affect the behavior of supermarket shoppers, Journal of Marketing, 46(3), pp.86-91. 1982

[9] Milliman, R. E.: The influence of background music on the behavior of restaurant patrons, Journal of Consumer Research, 13(2), pp.286-289, 1986.

[10] Chebat, J. C., Gelinas-Chebat, C., and Filiatrault, P.: Interactive effects of musical and visual cues on time perception: an appliciation to waiting lines in banks, Perceptual and Motor skills, 77(3), pp.995-1020, 1993.

[11] Oakes, S.: Music tempo and waiting perceptions, Psychology and Marketing, 20(8), pp.685-786, 2003.

[12］松田憲, 一川誠, 矢倉由果里 : BGM $の$ 音楽的特徵が聴覚 的時間評価に及ほす影響：テンポと音符に基づく検討, 日本感性工学会論文誌, 12(4), pp.493-498, 2013.

[13] Gundlach, R. H.: Factors determining the characteristics of musical phrases, American Journal of Psychology, 47, pp.624-643, 1935.

[14] Hevner, K.: The affective value of pitch and tempo in music, American Journal of Psychology, 49, pp.621-630, 1937.

[15］松田憲, 堀江悠美, 一川誠：BGM聴取時の心拍数 - 体温 · 血圧が時間評価に及ぼす影響, 日本認知科学会 28 回大会 論文集, pp.636-642，2011.

[16] Altshuler, I. M.: The past, present and future of musical therapy, Music therapy, pp.24-35, 1954.

[17］武中美佳子, 岡井沙智子, 小原依子, 井上健 : 心拍を基準 としたテンポのリズム聴取による生理反応に関する研究,
臨床教育心理学研究, 31, pp.43-55, 2005.

［18］堀田晴子，澤村貫太，井上健：被験者の心拍数に応じた テンポによる音楽聴取時の心拍変動について, 臨床教育心 理学研究, 33, pp.1-8, 2007.

[19］鹿野輝三：時間評価に対する音楽刺激の影響，金城学院大 学論集, 20, pp.79-94, 1995

[20］一川誠：大人の時間はなぜ短いのか，集英社新書， 2008

[21] Frankenhaeuser, M.: Estimation of time: An experimental study, Stockholm, Almqvist \& Wiksell, 1959.

[22］アメリカスポーツ医学会 (編) ・ 日本体力医学会体力科学編 集委員会 (監訳)：運動処方の指針：運動負荷試験と運動プ ログラム 原書第 8版, 南江堂, 2011

[23］厚生労働省：健康づくりのための運動指針, www.mhlw.go.jp/shingi/2006/07/dl/s0725-9f.pdf

[24] Hoagland, H.: The physiological control of judgments of duration: Evidence for a chemical clock, Journal of General Psychology, 9, pp.260-287, 1933.

[25] Hoagland, H.: Some biochemical considerations of time, In J. T. Fraser (Ed.), The voices of time, Amherst, MA: The University of Massachusetts Press, pp. 312-329, 1981.

[26］高津理美, 山崎昌廣, 長谷川博：運動後の回復過程における 体温調節時反応の性差, 体力科学, 57, pp.295-304, 2008.

[27] Fanger, P. O.: Thermal comfort. Danish, Technical Press, 1970.

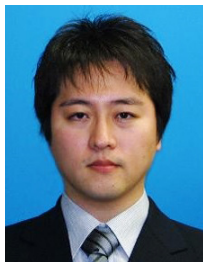

\section{松田 憲(正会員)}

2005 年 京都大学大学院教育学研究科博士後 期課程修了.2007年山口大学大学院理工学 研究科講師, 2014年 同准教授. 現在に至る. 博士 (教育学)。心理学の実験手法を用いて, 単純接触効果や概念形成，リスク認知，広告 効果, ノスタルジア, 時間評価の研究を行っている. 日本心理 学会, 日本認知科学会, 日本認知心理学会, Cognitive Science Society, Psychonomic Society各会員.

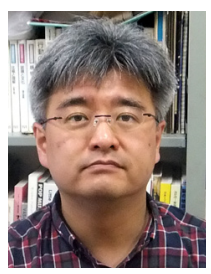

一川 誠 (正会員)

1994年 大阪市立大学大学院文学研究科博士後 期課程修了。博士 (文学)。1994年 ヨーク大 学視覚研究所博士研究員. 1997 年 山口大学工 学部講師, 2000年 同助教授. 2006年 千葉大 学文学部助教授, 2013 年 同教授. 現在に至る. 知覚, 認知, 感性領域における実験心理学の研究に従事. 日本心理 学会, 日本視覚学会, 日本基礎心理学会, 日本認知心理学会, 日本 時間学会, Association for Research on Vision and Ophthalmology, Vision Sciences Society 各会員.

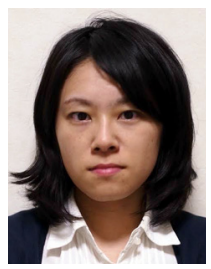

橘 佳奈 (非会員)

2013年 山口大学工学部感性デザイン工学科 卒業。学士 (工学)。現在は神戸すまいまち づくり公社に在職. 在学中は, 心拍数と音楽 聴取時の時間評価についての研究に従事 